\title{
PENGARUH KEMANDIRIAN BELAJAR SISWA TERHADAP PRESTASI BELAJAR DI SDN 03 LIMBOTO BARAT KABUPATEN GORONTALO
}

\author{
Finartin Uki, Asni Ilham, \\ Universitas Negeri Gorontalo \\ finartinuki81@gmail.com, asniilham59@yahoo.com
}

Received: 13 Desember 2019; Revised: 24 Desember 2019; Accepted: 3 Januari 2020

\begin{abstract}
ABSTRAK
Permasalahan yang menjadi fokus penelitian ini adalah rendahnya prestasi belajar siswa SDN 03 limboto Barat. Penelitian ini dilaksanakan di SDN 03 Limboto Barat dengan tujuan untuk mengetahui pengaruh kemandirian belajar siswa terhadap prestasi belajar. Penelitian ini menggunakan pendekatan kuantitatif. Teknik pengumpulan data yang digunakan adalah angket dan studi dokumen. Teknik analisis data yang digunakan ialah analisis regresi dan korelasi. Anggota populasi pada penelitian ini berjumlah 130 orang, sampel yang digunakan diambil dari populasi tersebut dengan menggunakan teknik Proportionate Sratified Random Sampling yaitu 34 siswa. Berdasarkan hasil penelitian diperoleh bentuk persamaan regresi linier sederhana $\hat{Y}=34,96+0,58 X$ sehingga dapat disimpulkan variabel X (Kemandirian Belajar) diikuti variabel Y (Prestasi belajar siswa). Kemudian dari hasil perhitungan koefisien korelasi diperoleh $\mathrm{r}=0,852$ dengan koefisien determinasi $\mathrm{r}^{2}=0,7259$. Uji signifikan koefisien korelasi memperoleh hasil perhitungan diperoleh harga $\mathrm{t}$ hitung sebesar $=9,22$ sedangkan dari daftar distribusi $\mathrm{t}$ pada taraf $5 \%$ diproleh $t$ daftar $=1,69$. Ternyata harga $t$ hitung lebih besar dari $t$ daftar, atau harga $t$ hitung berada di luar daerah penerimaan Ho. Sehingga dapat disimpulkan bahwa Ho ditolak dan menerima Ha, dengan demikian dapat disimpulkan bahwa terdapat pengaruh antara kemandirian belajar dengan prestasi belajar siswa.
\end{abstract}

Kata Kunci: Kemandirian Belajar,Prestasi Belajar Siswa

\section{PENDAHULUAN}

Prestasi belajar merupakan suatu masalah yang sangat potensial dalam sejarah kehidupan manusia karena sepanjang rentang kehidupannya manusia selalu mengejar prestasi menurut bidang dan kemampuan masing-masing.

Arikunto (2006:276) menyebutkan bahwa Prestasi harus mencerminkan tingkatan-tingkatan siswa sejauh mana telah dapat mencapai tujuan yang ditetapkan setiap bidang studi. Simbol yang digunakan untuk menyatakan nilai, baik huruf maupun angka, hendaknya merupakan gambaran tentang prestasi saja. Abu Ahmadi dan Widodo Supriyono dalam bukunya bahwa, Prestasi belajar siswa banyak di pengaruhi berbagai faktor, baik dalam dirinya (internal) maupun dari luar dirinya (eksternal).

Berdasarkan hasil observasi saya di SDN 3 Limboto barat banyak Siswa yang mengalami masalah prestasi belajar, sebab tidak adanya inisiatif dari dalam diri siswa untuk belajar mandiri, selalu bergantung kepada guru, jika tidak ada guru yang masuk dalam kelas memberikan pelajaran maka didalam kelas tersebut tidak ada kegiatan pembelajaran dan siswa hanya bermain. Maka dari itu Peningkatan kemandirian belajar 


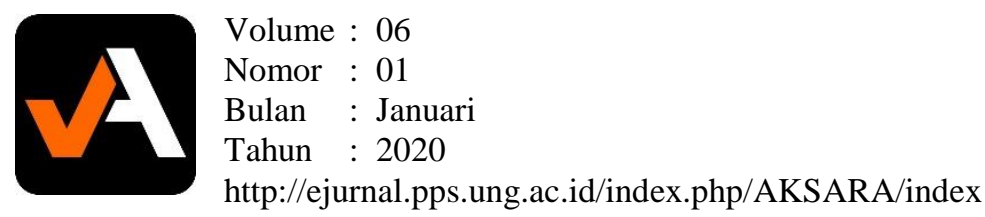

siswa sangat diperlukan mengingat bahwa prestasi belajar pada umumnya meningkat jika kemandirian untuk belajar bertambah.

Kemandirian belajar adalah aktivitas belajar yang dilakukan oleh siswa dengan kebebasannya dalam menentukan dan mengelola sendiri bahan ajar, waktu, tempat, dan memanfaatkkan berbagai sumber belajar yang diperlukan. Kebebasan tersebut diharapkan siswa memiliki kemampuan dalam mengelola cara belajar, memiliki rasa tanggung jawab yang tinggi dan terampil memanfaatkan sumber belajar.

Jadi jika siswa aktif dalam proses pembelajaran dan inisiatif untuk belajar sendiri tanpa menggantungkan diri pada orang lain maka prestasi belajar akan meningkat.

Berdasarkan latar belakang di atas peneliti ingin melakukan penelitian dengan judul "Pengaruh Kemandirian Belajar Siswa Terhadap Prestasi Belajar di SDN 03 Limboto Barat".

\section{KAJIAN TEORI \\ PRESTASI BELAJAR}

Ahli pendidikan modern merumuskan belajar adalah suatu bentuk pertumbuhan atau perubahan dalam diri sesorang yang dinyatakan dalam cara-cara bertingkah laku yang baru berkat pengalaman dan latihan. Belajar merupakan suatu perubahan dalam tingkah laku, di mana perubahan itu dapat mengarah kepada tingkah laku yang lebih baik, tetapi jug ada kemungkinan mengarah kepada tingkah laku yang lebih buruk.

Ahmad susanto (2013:4) belajar adalah suatu aktivitas yang dilakukan seseorang dengan sengaja dalam keadaan sadar untuk memperoleh suatu konsep, pemahaman, atau pengetahuan baru sehingga memugkinkan seseorang terjadinya perubahan perilaku yang relatif tetap baik dalam berfikir, merasa, maupun dalambertindak.

Marsun dan Martaniah dalam Hidayat(2013:83) berpendapat bahwa prestasi belajar merupakan hasil kegiatan belajar, yaitu sejauh mana peserta didik menguasai bahan pelajaran yang diajarkan, yang diikuti oleh munculnya perasaan puas bahwa ia telah melakukan sesuatu dengan baik. Hal ini berarti prestasi belajar hanya bisa diketahui jika telah dilakukan penilaian terhadap hasil belajar siswa.

Menurut Poerwodarminto dalam Hidayat (2013:83) yang dimaksud dengan prestasi adalah hasil yang telah dicapai, dilakukan atau dikerjakan oleh seseorang. Sedangkan prestasi belajar itu sendiri diartikan sebagai prestasi yang dicapai oleh seorang siswa pada jangka waktu tertentu dan dicatat dalam buku rapor sekolah. Arikunto (2006:276) menyebutkan bahwa Prestasi harus mencerminkan tingkatantingkatan siswa sejauh mana telah dapat mencapai tujuan yang ditetapkan setiap bidang studi. Simbol yang digunakan untuk menyatakan nilai, baik huruf maupun angka, hendaknya merupakan gambaran tentang prestasi saja.

Abu Ahmadi dan Widodo Supriyono dalam bukunya bahwa, Prestasi belajar siswa banyak di pengaruhi berbagai faktor, baik dalam dirinya (internal) maupun dari luar dirinya (eksternal).

\section{KEMANDIRIAN BELAJAR}

Menurut Haris Mujiman (2007:1) "Kemandirian Belajar dapat diartikan sebagai sifat serta kemampuan yang dimiliki siswa untuk melakukan kegiatan belajar aktif, yang didorong oleh motif untuk menguasai sesuatu kompetensi yang telah dimiliki". Menurut Abu Ahmadi (2004:31), "Kemandirian Belajar adalah sebagai belajar mandiri, tidak 
menggantungkan diri pada orang lain". Siswa dituntut memiliki inisiatif, keaktifan dan keterlibatan dalam proses pembelajaran untuk meningkatkan Prestasi Belajar.

Menurut Yamin (2008:19) manfaat kemandirian belajar antara lain mampu memupuk tanggung jawab, meningkatkan keterampila, memecahkan masalah, mengambil keputusan, berfikir kreatif, berfikir kritis, percaya diri yang kuat serta mampu menjadi guru bagi dirinya sendiri.

Muhammad Ali menjelaskan bahwa ada sejumlah faktor yang sering disebut sebagai korelat bagi perkembangan kemandirian, yaitu gen, pola asuh orang tua, sistem pendidikan di sekolah dan sistem kehidupan di masyarakat :

Menurut Rusman (2010:366) mengatakan bahwa siswa yang sudah mandiri mempunyai karakteristik atara lain:(1)Siswa sudah mengetahui dengan pasti apa yang ingin di capai dalam kegiatan belajarnya(2)Siswa sudah dapat memilih sumber belajarnya sendiri(3)Siswa sudah dapat menilai tingkat kemampuan yang diperlukan untuk melaksanakan pekerjaan atau memecahkan permasalahan yang diumpai dalam kehidupannya

Menurut Marsun dalam Imadah (2011:24) Indikator-indikator kemandirian dalam penelitian ini adalah sebagai berikut:(1) Adanya Tendensi Bebas (2) inisiatif (3) Kreatif (4) Progresif (5) Ulet (6) Percaya diri (7) Pengendalian dari dalam.

\section{METODE PENELITIAN}

Penelitian ini dilaksanakan di SDN 03 Limboto Barat pada semester genap tahun ajaran 2018/2019. Lokasinya terletak di desa Pone Kecamatan Limboto Barat Kabupaten Gorontalo.

Metode penelitian yang digunakan dalam penelitian ini adalah metode ex post facto. Menurut Kerlinger dalam Emzir (2013:119) Metode ex post facto adalah penyelidikan empiris yang sistematis di mana ilmuan tidak mengendalikan variabel bebas secara langsung karena eksistensi dari variabel tersebut telah terjadi atau karena variabel tersebut pada dasarnya tidak dapat dimanipulasi.

Pendekatan yang digunakan dalam penelitian ini adalah pendekatan kuantitatif. Penelitian kuatitatif menekankan pada adanya pengujian hipotesis, mementingkan proses pengukuran melalui data-data, uji statistic dan hubungan antar variabel.

Variabel Independen dalam penelitian ini adalah kemandirian belajar (X). dengan indikator adanya tendensi bebas, inisiatif, kreatif, progresif, ulet, Percaya diri, dan pengendalian dari dalam. Variabel dependen dalam penelitian ini adalah Prestasi Belajar (Y).yang diambil dari nilai raport siswa. Jadi pada penelitian ini variabel penelitiannya adalah kemandirian belajar siswa (X) dan Prestasi belajar (Y).

Populasi dalam penelitian ini adalah seluruh siswa SDN 03 Limboto barat yang terdiri dari 130 siswa. sampel dari penelitian ini menggunakan teknik Proportionate Sratified Random Sampling dimana sampel yang digunakan diambil dari sebagian jumlah populasi. Dalam penelitian ini peneliti mengambil sampel siswa kelas IV yang berjumalah 18 orang dan kelas V yang berjumlah 16 orang. Sehingga total sampel yang digunakan dalam penelitian ini sejumlah 34 orang. Teknik pengumpulan data dalam penelitian adalah angket dan dokumentasi. Sedangkan pengujian instrument penelitian menggunakan uji validitas dan reliabilitas.

\section{HASIL PENELITIAN DAN PEMBAHASAN}

Penelitian ini dilaksanakan di SDN 03 Limboto barat pada bulan april 2019. Data penelitian ini diperoleh dari angket kemandirian belajar dan studi dokumen (Nilai 
Raport) oleh siswa kelas IV dan kelas V SDN 03 Limboto Barat yang berjumlah 34 siswa. Data dalam penelitian ini diolah dengan perhitungan statistika untuk memperoleh nilai pengaruh kemandirian belajar siswa terhadap prestasi belajar di SDN 03 Limboto Barat. Berikut adalah hasil penelitian berupa pengujian normalitas data, uji regresi, uji linieritas regresi, uji korelasi, dan uji t.

\section{Uji Normalitas Data}

Tabel 4.1 Uji Normalitas data

\begin{tabular}{lccccccc}
\hline & \multicolumn{3}{c}{ Kolmogorov-Smirnov $^{\mathrm{a}}$} & \multicolumn{3}{c}{ Shapiro-Wilk } \\
& Statistic & df & Sig. & Statistic & df & Sig. \\
\hline Kemandirian_Belaj & .098 & 34 & $.200^{*}$ & .980 & 34 & .771 \\
ar & .118 & 34 & $.200^{*}$ & .952 & 34 & .146 \\
Prestasi_Belajar & & & & & & & \\
\hline
\end{tabular}

Hasil perthitungan kemandirian belajar (Kolmogrov smirnov) menunjukan 0,200>0,05 maka dapat disimpulkan data berdistribusi normal, sedangkan data Prestasi belajar (kolmogrov smirnov) menunjukan 0,200>0,05 maka dapat disimpulkan bahwa data berdistribusi normal. Hasil perhitungan data kemandirian belajar (Shafiro wilk) menunjukan 0,771>0,05 maka dapat disimpulkan data berdistribusi normal, sedangkan data prestasi belajar (shafiro wilk) menunjukan 0,146>0,05, maka dapat disimpulkan data berdistribusi normal.

\section{PENGUJIAN HIPOTESIS}

Persamaan regresi linier diperoleh persamaan $\widehat{Y}=34,96+0,58 x$ dimana setiap kenaikan pada satu satuan skor pada variabel X (Kemandirian belajar) diikuti kenaikan variabel Y (Prestasi belajar) sebesar 0,58 dan garis potong variabel Y terhadap X saat $\mathrm{X}=0$ adalah 34,96 .

Berdasarkan perhitungan diperoleh nilai uji regresi nilai signifikan = 0,098>0,05 maka dapat disimpulkan terdapat hubungan linear secara signifikan antara variabel X (kemandirian Belajar) dengan variabel Y (prestasi belajar).

Dari hasil analisis korelasi sederhana (r) antara kemandirian belajar dengan prestasi belajar siswa (r) adalah 0,852. Hal ini menunjukan bahwa terdapat pengaruh antara kemandirian belajar dengan prestasi belajar siswa. hasil nilai pearson korelasi sempurna, sedangkan arah hubungan adalah positif karena nilai positif berarti semakin tinggi kemandirian belajar siswa maka semakin meningkat prestasi belajar siswa.

Hubungan antara kemandirian belajar dengan prestasi belajar siswa diperolah $\mathrm{r}=$ 0,852 maka koefisien determinasi $\left(\mathrm{r}^{2}\right)$ variabel $\mathrm{X}$ (kemandirian belajar) dengan $\mathrm{Y}$ (prestasi belajar) sebesar $0,852^{2}=0,7259 \times 100 \%=72.59 \%$. Dengan demikian dapat dikatakan 72,59\% prestasi belajar dipengaruhi oleh kemandirian belajar dan 27,41\% sisanya dijelaskan oleh variabel lain yang tidak diteliti dalam penelitian ini.

Berdasarkan pengolahan data diperoleh harga t sebesar 9,22 sedangkan dari taraf distribusi t pada taraf nyata $5 \%$ diperoleh $t=9,22$ ternyata harga $t_{\text {hitung }} 9,22>t$-daftar

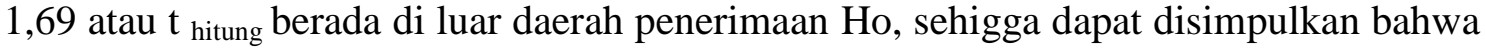
Ho ditolak dan menerima Ha, dengan demikian dapat disimpulkan bahwa koefisien korelasi antara kemandirian belajar dengan prestasi belajar siswa signifikan atau dapat diterima. 
sesuai dengan hasil penelitian ilmiah, indikator tersebut (variabel $\mathrm{X}$ ) dapat memberikan dampak atau memiliki pengaruh pada variabel $\mathrm{Y}$ yaitu prestasi belajar siswa yang dilihat dari nilai rata-rata (buku laporan pendidikan) yang optimal. Selanjutnya, pengujian koefisien korelasi sederhana yang dimaksudkan adalah untuk mengetahui berapa kekuatan atau derajat pengaruh kemandirian belajar dengan prestasi belajar siswa. Oleh karena itu, berdasarkan hasil perhitungan diperoleh koefisien korelasi $r=0,852$ dan koefisien determinasinya $\mathrm{r}^{2}=0,852^{2}=0,7259 \times 100 \%=72.59 \%$.

Hal ini mengandung makna bahwa 72,59\% variansi yang terjadi pada variabel $Y$ prestasi belajar siswa dapat dituangkan oleh variabel $\mathrm{X}$ dengan persamaan regresi $\hat{\mathrm{Y}}=$ $34,96+0,58 \mathrm{X}$ dan $27,41 \%$ ditentukan oleh variabel lain yang tidak diteliti oleh peneliti, sehingga secara tidak langsung hasil penelitian ini masih memberikan kepada orang lain untuk melanjukan dengan melakukan peninjauan kembali dari aspek yang lainnya.

Hasil penelitian ini mendukung kajian sebelumnya yang menyatakan bahwa dalam melakukan aktivitas belajar, setiap siswa dituntut kemandirian belajarnya. Karena adanya sikap kemandirian siswa dapat mencapai hasil belajar atau prestasi belajar yang optimal. Hail ini sejalan dengan hasil penelitian yang telah dilakukan menunjukan bahwa sebesar $72,59 \%$ prestasi belajar siswa dipengaruhi oleh kemandirian belajar siswa. Hal ini berarti bahwa setiap siswa yang ingin memiliki prestasi belajar yang tinggi maka harus menciptakan kemandirian dalam belajar. Seperti yang dikemukakan oleh Abu Ahmadi (2004:31) berpendapat bahwa kemandirian belajar adalah sebagai belajar mandiri, tidak menggantungkan diri pada orang lain, siswa dituntut memiliki inisiatif, keaktifan dan keterlibatan dalam proses pembelajaran untuk meningkatkan prestasi belajar. Degan demikian kemandirian belajar merupakan salah satu faktor internal yang mempengaruhi prestasi belajar.

Prestasi belajar yang tinggi dapat dicapai jika siswa mampu meningkatkan kemandirian belajar melalui tindakan yang dilakukan atas kehendak sendiri bukan karena kehendak orang lain (adanya tendensi bebas), mampu berfikir dan bertindak secara logis, original, berfikir kritis dan bertanggung jawab (Inisiatif), kreatif, progresif, ulet, percaya diri, dan adanya perasaan mampu mengendalikan tindakannya.

\section{SIMPULAN}

Berdasarkan analisis data maka dapat disimpulkan bahwa pengaruh kemandirian belajar dengan prestasi belajar siswa dalam bentuk persamaan regresi linear sederhana, yakni $\widehat{Y}=34,96+0,58 \mathrm{X}$ artinya dimana setiap kenaikan pada satu satuan pada variabel X (Kemandirian belajar) akan diikuti kenaikan variabel Y (prestasil belajar). Hasil perhitungan koefisien korelasi diperoleh $\mathrm{r}=0,852$ dengan koefisien determinasi $r^{2}=0,852^{2}=0,7259 \times 100 \%=72.59 \%$.

hasil ini menunjukan bahwa konstribusi kemandirian belajar terhadap prestasi belajar adalah $72.59 \%$. sedangkan sisanya $27.41 \%$ dijelaskan oleh variabel lain yang tidak diteliti dalam penelitian ini. Berdasarkan pengolahan data uji $t$ diperoleh harga $t$ sebesar 9,22 sedangkan dari taraf distribusi t pada taraf nyata 5\% diperoleh $\mathrm{t}=1,69$ ternyata harga $t_{\text {hitung }} 9,22>\mathrm{t}$-daftar 1,69 atau $\mathrm{t}$ hitung berada di luar daerah penerimaan Ho, sehigga dapat disimpulkan bahwa Ho ditolak dan menerima Ha, dengan demikian dapat disimpulkan bahwa koefisien korelasi antara kemandirian belajar dengan prestasi belajar siswa signifikan atau dapat diterima. Dengan demikian hipotesis pada penelitian ini yang berbunyi "terdapat pengaruh antara kemandirian belajar dengan prestasi belajar siswa di SDN 03 Limboto Barat” dapat diterima. 


Volume : 06
Nomor : 01
Bulan : Januari
Tahun : 2020
http://ejurnal.pps.ung.ac.id/index.php/AKSARA/index

\section{SARAN}

Pada dasarnya kemandirian belajar mempunyai pengaruh terhadap prestasi belajar siswa. Maka dari itu saran saya bagi guru dan orang tua siswa agar mendorong kemandirian belajar siswa. Dengan kemandirian belajar yang tinggi akan meningkat pula prestasi belajar siswa. Dengan demikian pula kerjasama antara guru dan orang tua siswa pada SDN 03 Limboto Barat untuk lebih memperhatikan faktor-faktor peningkatan prestasi belajar khususnya kemandirian belajar siswa.

\section{DAFTAR PUSTAKA}

Ahmadi, Abu dan Widodo Supriyono. 2004. Psikologi Belajar. Jakarta: Rineka

Aini Pratistya Nor \& Abdullah Taman. 2012. Pengaruh Kemandirian Belajar Dan Lingkungan Belajar Siswa Terhadap Prestasi Belajar Akuntansi Siswa Kelas Xi Ips Sma Negeri 1 Sewon Bantul Tahun Ajaran 2011/2012. Jurnal Pendidikan Akuntansi Indonesia, Vol. X, No. 1.

Ali M, dan Asrori M.2009.Psikologi Remaja. Jakarta: Bumi

A.M. Sardiman. 2011. Interaksi dan Motivasi Belajar Mengajar. Jakarta: Rajawali Press.

Arikunto, Suharsimi. 2006. Prosedur Penelitian Suatu Pendekatan Praktik (Edisi Revisi VI). Jakarta : Rineka Cipta.

Ariska,Elsa. 2016. Pengaruh Kemandirian Belajar di Sekolah Terhadap Prestasi Belajar IPA Kelas V SDN Gugus Ki Hajar Dewantara Kecamatan Tugu Kota Semarang.Skripsi. Semarang. Universitas Negeri Semarang (UNNES)

Awalludin, dkk. 2008. Statistika Pendidikan. Gorontalo: Departemen Pendidikan Nasional

Emzir. 2013. Metodologi Penelitian Pendidikan: Kuantitatif dan Kualitatif. Jakarta: Raja Grafindo Persada

Imadah. 2011. Pengaruh Kemandirian Belajar Siswa Terhadap Prestasi Belajar Mata Pelajaran Fiqih Kelas VIII MTs Negeri Kota Magelang tahun pelajaran 2010/2011. Skripsi

Fahradina, Nova dkk. 2014. Peningkatan Kemampuan Komunikasi Matematis dan Kemandirian Belajar Siswa SMP dengan menggunakan model Investigasi Kelompok. urnal Didaktik Matematika Vol. 1, No. 1.

Huri, Suhendri.2010. Pengaruh Kecerdasan Matematis-Logis dan Kemandirian Belajar Terhadap Hasil Belajar Matematika. Jurnal Formatif 1(1): 29-39

Mujiman, Haris. 2007. Manajemen Pelatihan Berbasis Belajar Mandiri. Yogyakarta: Mitra Cendekia.

Paulina, Panen, dkk. 2001. Konstruksivisme Dalam Pembelajaran. Jakarta : PPAUT Dirjen Dikti Depdiknas.

Pratiwi, NK. 2015. Pengaruh Tingkat Pendidikan, Perhatian Orang Tua, Dan Minat Belajar Siswa Terhadap Prestasi Belajar Bahasa Indonesia Siswa Smk Kesehatan Di Kota Tangerang. Jurnal Pujangga Volume 1, Nomor 2.

Rusman. 2010. Model-Model Pembelajaran (Mengembangkan profesionalisme guru). Jakarta: Raja Grafindo Persada

Setiawati, Linda. 2015. Faktor-Faktor yang Mempengaruhi Prestasi Belajar Praktik Kejuruan Siswa SMK Program Studi Keahlian Teknik Komputer dan Informatika. Jurnal Pendidikan Vokasi, Vol 5, Nomor 3. 
Sudjana. 2002. Metode Statistika. Edisi keenam. Bandung : Tarsito.

Sugiyono. 2013. Metode Penelitian Pendidikan Pendekatan Kuantitatif, Kualitatif, dan $R \& D$. Bandung: Alfabeta.

.2017. Metode Penelitian Pendidikan Pendekatan Kuantitatif, Kualitatif, dan $R \& D$ Bandung: Alfabeta

Sumini, Endang. Pengaruh Kemandirian Belajar Terhadap Prestasi Belajar IPS siswa Kelas IV SD Negeri Terbansari 1 yogyakarta tahu Pelajaran 2051/2016. Skripsi.Yogyakarta. Universitas PGRI Yogyakarta

Surya, Hendra. 2003. Kiat Mengajak Anak Belajar dan Berprestasi. Jakarta : Gramedia Suryabrata, Sumadi. 2006. Psikologi Pendidikan. Jakarta: Raja Grafindo Persada.

Susanto, Ahmad. 2013. Teori Belajar \& Pembelajaran di Sekolah Dasar. Jakarta: Prenadamedia Group.

Tim Penyusun Kamus Pusat Bahasa,2002.Kamus Besar Bahasa Indonesia. Jakarta : Balai Pustaka

Tirtarahardja, Umar dan S.L La Sulo. 2005. Pengantar Pendidikan . Jakarta: Rineka Cipta

Yamin,Martinis. 2008. Taktik Mengembangkan Kemampuan Individu Siswa. Jakarta: Gaung Persada Press 